\title{
ASO Author Reflection: Trimodality Therapy Offers Survival Advantage in Metastatic Male Breast Cancer
}

\author{
Kelly Stahl, MD, MSCR, Daleela Dodge, MD, FACS, William Wong, MD, and Chan Shen, PhD \\ College of Medicine, Surgery, The Pennsylvania State University, Hershey
}

\section{PAST}

For males with metastatic breast cancer, systemic therapy has been the cornerstone of treatment. Treatment algorithms parallel female breast cancer treatments, where surgery remains controversial and not currently recommended by National Comprehensive Cancer Network guidelines. ${ }^{1}$ Previous retrospective cohort studies in males have suggested that surgery is beneficial to survival; ${ }^{2,3}$ however, survival benefit by the type of treatment received based on a patients' hormone status has yet to be studied.

\section{PRESENT}

Our study used the National Cancer Database to investigate men who presented with de novo stage IV breast cancer and known estrogen receptor (ER) and progesterone receptor (PR) statuses, who had undergone systemic therapy with or without surgical intervention. Patients who died within the first 6 months were excluded. We found that, in male patients with de novo stage IV breast cancer who were $\mathrm{ER}+$ or $\mathrm{PR}+$, those who had surgery, radiation therapy, and systemic therapy (trimodality) had a significant survival advantage compared with patients who received only systemic therapy. Our data also showed a downward trend in the utilization of surgery over the years in this cohort. ${ }^{4}$

(C) Society of Surgical Oncology 2021

First Received: 19 August 2021

Accepted: 21 August 2021;

Published Online: 16 September 2021

C. Shen, $\mathrm{PhD}$

e-mail: chanshen@psu.edu

\section{FUTURE}

Trimodality therapy should strongly be considered for men with de novo stage IV breast cancer, which is in concordance with similar findings in the female breast cancer literature. ${ }^{5}$ Given our small sample size, we were unable to analyze patients by human epidermal growth factor receptor 2 (HER2) status. However, we postulate that an even greater benefit could be seen in HER2+ patients. Given the rarity of this disease, randomized controlled trials are not feasible. Therefore, we recommend evaluating real-world evidence, especially large retrospective cohort studies, to guide the treatment of men with de novo stage IV breast cancer.

\section{REFERENCES}

1. Gradishar WJ, Anderson BO, Abraham J, Aft R, Agnese D, Allison KH, Blair SL, Burstein HJ, Dang C, Elias AD, Giordano SH. Breast cancer, version 3.2020, NCCN clinical practice guidelines in oncology. J Natl Compr Canc Netw. 2020 1;18(4):452-78.

2. Muzaffar M, Kachare S, Vohra N. Impact of primary tumor surgery in stage IV male breast cancer. Clin Breast Cancer. 2017;17(3):e143-9.

3. Chen W, Huang Y, Lewis GD, et al. Treatment outcomes and prognostic factors in male patients with stage IV breast cancer: a population-based study. Clin Breast Cancer. 2018;18(1):e97-105.

4. Stahl KA, Wong W, Olecki EJ, et al. Benefits of trimodality therapy compared with systemic therapy alone in male patients with stage IV breast cancer. Ann Surg Oncol. 2021. https://doi.org/ 10.1245/s10434-021-10729-0.

5. Stahl K, Wong W, Dodge D, et al. Benefits of surgical treatment of stage IV breast cancer for patients with known hormone receptor and HER2 status. Ann Surg Oncol. 2021;28(5):2646-58.

Publisher's Note Springer Nature remains neutral with regard to jurisdictional claims in published maps and institutional affiliations. 